\title{
Intramolecular hydroamination of alkynic sulfon- amides catalyzed by a gold-triethynylphosphine complex: Construction of azepine frameworks by 7-exo-dig cyclization
}

Hideto Ito, Tomoya Harada, Hirohisa Ohmiya and Masaya Sawamura*

Full Research Paper

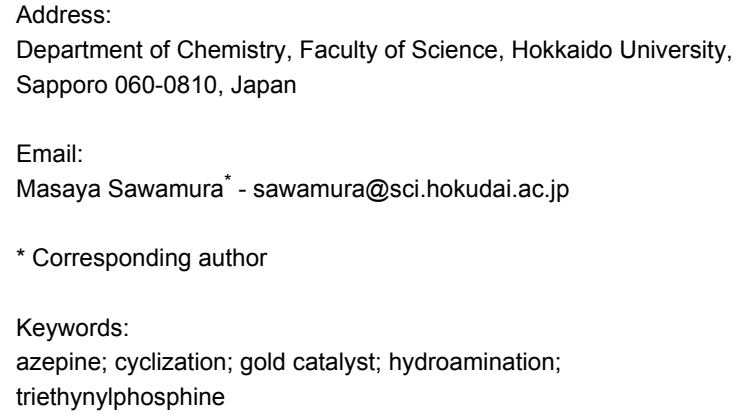

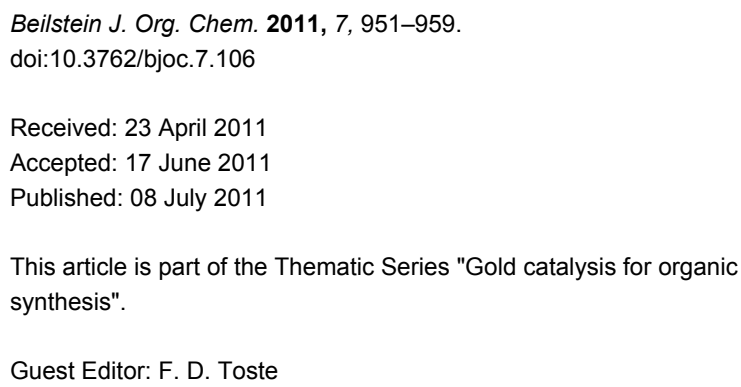

(C) 2011 Ito et al; licensee Beilstein-Institut. License and terms: see end of document.

\begin{abstract}
The gold-catalyzed, seven-membered ring forming, intramolecular hydroamination of alkynic sulfonamides has been investigated. The protocol, with a semihollow-shaped triethynylphosphine as a ligand for gold, allowed the synthesis of a variety of azepine derivatives, which are difficult to access by other methods. Both alkynic sulfoamides with a flexible linear chain and the benzenefused substrates underwent 7-exo-dig cyclization to afford the nitrogen-containing heterocyclic seven-membered rings, such as tetrahydroazepine and dihydrobenzazepine, in good yields.
\end{abstract}

\section{Introduction}

Nitrogen-containing heterocyclic seven-membered rings are found in many biologically active natural products and pharmaceuticals, such as (-)-tuberosutemonin (1) [1-6], related Stemona alkaloids [7], Cephalotaxus alkaloid (-)-cephalotaxine (2) [8-12], and SB-462795 (3) (Figure 1) [13-16]. Among a number of different approaches for the construction of N-heterocyclic compounds, metal-catalyzed intramolecular hydroamination of unactivated $\mathrm{C}-\mathrm{C}$ multiple bonds is particularly straightforward and efficient [17,18]. Specifically, goldcatalyzed intramolecular hydroaminations of alkynes, alkenes and allenes show remarkable efficiency [19-28]. Unfortunately, however, the application of these methodologies to the synthesis of the N-heterocyclic seven-membered ring compounds is hampered by the low efficiency of seven-membered ring formations. Despite extensive studies on the gold-catalyzed intramolecular hydroamination of alkynes [19-51], seven-membered 
ring formation is rare and is limited to the cases where the substrate is preorganized for cyclization: The substrates must have geminal disubstitution or ring fusion within a linker chain connecting the attacking nitrogen atom and the alkyne moiety. It should be noted, however, that 7-“endo"-dig cyclizations of (o-alkynyl)phenylacetamides and a diynamide were achieved with gold and palladium complexes [39,46,52,53], and the zinccatalyzed 7-exo-dig cyclization was reported specifically for a propargyl ether substrate [54].

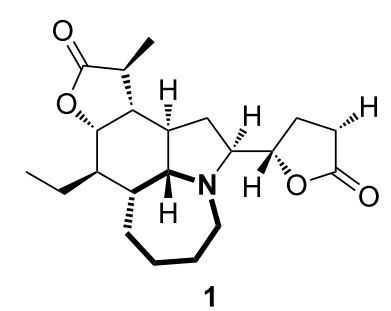

(-)-tuberostemonine

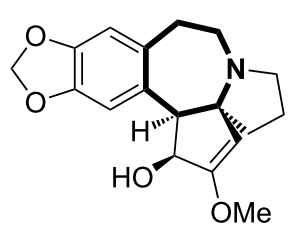

2

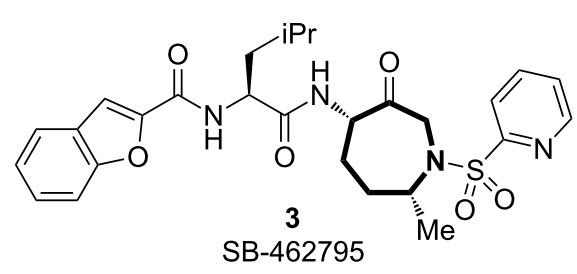

Figure 1: Azepine frameworks found in natural products and pharmaceuticals.

Previously, we reported that semihollow-shaped triethylnylphosphine L1 (Figure 2) exerted marked acceleration effects in the gold(I)-catalyzed Conia-ene reactions of acetylenic keto esters and enyne cycloisomerizations. The new catalytic system has expanded the scope of the reactions to six- and sevenmembered ring formations, which had been difficult with the conventional catalytic systems [55]. Furthermore, we found that L1-gold(I) complex efficiently catalyzed the cyclization of internal alkyne substrates, which had also been difficult due to the steric repulsion between a nucleophilic center and a terminal substituent on the alkyne moiety [56]. We proposed that the cavity in the ligand forces the nucleophilic center closer to the gold-bound alkyne, resulting in the entropy-based rate enhancement. Recently, we further developed the gold(I)-catalyzed 7-exo-dig cyclization of acetylenic silyl enol ethers with L1 [57].

In this context, we expected that the use of $\mathbf{L} \mathbf{1}$ as a ligand in the gold-catalyzed intramolecular hydroamination of alkynes would enable the construction of nitrogen-containing heterocyclic seven-membered rings, and we applied the triethynylphosphine-gold(I) catalytic systems to the synthesis of azepine derivatives through intramolecular hydroamination of alkynic

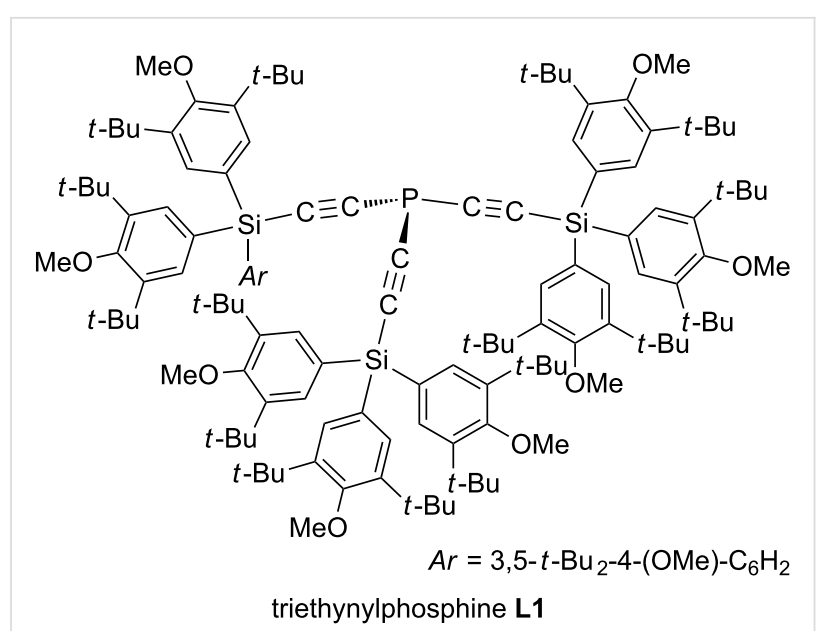

Figure 2: Semihollow-shaped triethynylphosphine L1.

sulfonamides. This article describes the results of the optimization of reaction conditions, exploration of substrate scope, and some mechanistic experiments.

\section{Results and Discussion Reaction conditions}

The reaction conditions were optimized for the cyclization of $N$-(6-heptyn-1-yl)-p-toluenesulfonamide (4a) (Table 1). The triethynylphosphine-gold complex $\left[\mathrm{Au}\left(\mathrm{NTf}_{2}\right)(\mathbf{L 1})\right](0.5 \mathrm{~mol} \%)$ catalyzed the cyclization of $\mathbf{4 a}(0.2 \mathrm{mmol})$ efficiently in $\mathrm{CH}_{2} \mathrm{Cl}_{2}$ $(1.0 \mathrm{~mL})$ at $25{ }^{\circ} \mathrm{C}(100 \%$ convn. of $\mathbf{4 a})$ to afford 4,5,6,7-tetrahydroazepine derivative 5a with $18 \mathrm{~h}$ reaction time in $82 \%$ isolated yield (Table 1, entry 1). This reaction seemed to proceed through 7-exo-dig cyclization, but an exomethylenetype cyclic product $\mathbf{6 a}$, which is a possible product of the 7-exodig cyclization [57], was not observed. The reaction under fourtimes-diluted conditions did not proceed to full conversion in the same reaction time (Table 1 , entry 2 ). The reaction time was shortened to $9 \mathrm{~h}$ by heating at $80{ }^{\circ} \mathrm{C}$, but this caused a slight decrease in the isolated yield of $\mathbf{5 a}$ (79\%) (Table 1, entry 3 ).

Among other solvents examined, toluene gave a result comparable with $\mathrm{CH}_{2} \mathrm{Cl}_{2}$ (Table 1, entries 1 and 4). On the other hand, polar and potentially coordinating solvents such as THF and $\mathrm{MeCN}$ were not effective in this reaction (Table 1, entries 5 and 6 ). The effect of the counter anion of the cationic gold complex is shown in Table 1, entries 1 and 7-9. While OTf ${ }^{-}$was as effective as $\mathrm{NTf}_{2}{ }^{-}$(Table 1, entry 7$), \mathrm{SbF}_{6}{ }^{-}$and $\mathrm{BF}_{4}{ }^{-}$inhibited the reaction completely (Table 1 , entries 8 and 9).

The ligand effect is evaluated in Table 1, entries 1 and 10-14. The reaction proceeded slowly, even with a conventional phosphine ligand $\mathrm{PPh}_{3}$, such that the starting material was not fully consumed even after $24 \mathrm{~h}$ and the yield was as low as $26 \%$ (Ta- 
Table 1: Optimization of reaction conditions for the gold-catalyzed intramolecular hydroamination of 4 a.

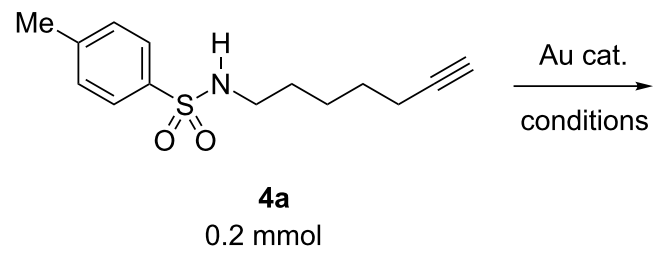

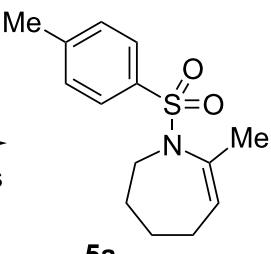

5 a

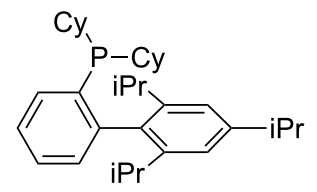

IPr

X-Phos

\begin{tabular}{|c|c|c|c|c|c|c|}
\hline entry & Au cat. (mol \%) & solvent $(m L)$ & temp. $\left({ }^{\circ} \mathrm{C}\right)$ & time $(\mathrm{h})$ & convn. $(\%)^{a}$ & yield orf $5(\%)^{a, b}$ \\
\hline 1 & {$\left[\mathrm{Au}\left(\mathrm{NTf}_{2}\right)(\mathrm{L} 1)\right](0.5)$} & $\mathrm{CH}_{2} \mathrm{Cl}_{2}(1.0)$ & 25 & 18 & 100 & $90(82)$ \\
\hline 2 & {$\left[\mathrm{Au}\left(\mathrm{NTf}_{2}\right)(\mathrm{L} 1)\right](0.5)$} & $\mathrm{CH}_{2} \mathrm{Cl}_{2}(4.0)$ & 25 & 18 & 87 & 85 \\
\hline 3 & {$\left[\mathrm{Au}\left(\mathrm{NTf}_{2}\right)(\mathrm{L} 1)\right](0.5)$} & DCE (1.0) & 80 & 9 & 100 & $83(79)$ \\
\hline 4 & {$\left[\mathrm{Au}\left(\mathrm{NTf}_{2}\right)(\mathrm{L} 1)\right](0.5)$} & toluene (1.0) & 25 & 18 & 98 & 97 \\
\hline 5 & {$\left[\mathrm{Au}\left(\mathrm{NTf}_{2}\right)(\mathrm{L} 1)\right](0.5)$} & THF (1.0) & 25 & 18 & 29 & 24 \\
\hline 6 & {$\left[\mathrm{Au}\left(\mathrm{NTf}_{2}\right)(\mathrm{L} 1)\right](0.5)$} & $\operatorname{MeCN}(1.0)$ & 25 & 18 & 0 & n. d. \\
\hline 7 & {$[\mathrm{Au}(\mathrm{OTf})(\mathrm{L} 1)](0.5)$} & $\mathrm{CH}_{2} \mathrm{Cl}_{2}(1.0)$ & 25 & 18 & 100 & $90(80)$ \\
\hline 8 & {$\left[\mathrm{Au}\left(\mathrm{SbF}_{6}\right)(\mathrm{L} 1)\right](0.5)$} & $\mathrm{CH}_{2} \mathrm{Cl}_{2}(1.0)$ & 25 & 18 & 14 & n. d. \\
\hline 9 & {$\left[\mathrm{Au}\left(\mathrm{BF}_{4}\right)(\mathrm{L} 1)\right](0.5)$} & $\mathrm{CH}_{2} \mathrm{Cl}_{2}(1.0)$ & 25 & 18 & 7 & n. d. \\
\hline 10 & {$\left[\mathrm{Au}\left(\mathrm{NTf}_{2}\right)\left(\mathrm{PPh}_{3}\right)\right](0.5)$} & $\mathrm{CH}_{2} \mathrm{Cl}_{2}(1.0)$ & 25 & 24 & 29 & $22(26)$ \\
\hline 11 & {$\left[\mathrm{Au}\left(\mathrm{NTf}_{2}\right)\left(\mathrm{PPh}_{3}\right)\right](5.0)$} & $\mathrm{CH}_{2} \mathrm{Cl}_{2}(1.0)$ & 25 & 18 & 100 & $66(64)$ \\
\hline 12 & {$\left[\mathrm{Au}\left(\mathrm{NTf}_{2}\right)\left\{\mathrm{P}(\mathrm{OPh})_{3}\right\}\right](0.5)$} & $\mathrm{CH}_{2} \mathrm{Cl}_{2}(1.0)$ & 25 & 18 & 54 & 39 \\
\hline 13 & {$\left[\mathrm{Au}\left(\mathrm{NTf}_{2}\right)(\mathrm{X}-\mathrm{Phos})\right](0.5)$} & $\mathrm{CH}_{2} \mathrm{Cl}_{2}(1.0)$ & 25 & 18 & 41 & 41 \\
\hline 14 & {$\left[\mathrm{Au}\left(\mathrm{NTf}_{2}\right)(\mathrm{IPr})\right](0.5)$} & $\mathrm{CH}_{2} \mathrm{Cl}_{2}(1.0)$ & 25 & 18 & 53 & 41 \\
\hline
\end{tabular}

a Determined by ${ }^{1} \mathrm{H}$ NMR. ${ }^{b}$ Isolated yield in parentheses.

ble 1, entry 10). Increasing the catalyst loading of $\left[\mathrm{Au}\left(\mathrm{NTf}_{2}\right)\left(\mathrm{PPh}_{3}\right)\right]$ to $5.0 \mathrm{~mol} \%$ caused full consumption of $\mathbf{4 a}$, but the cyclization product was obtained only in $64 \%$ yield (Table 1 , entry 11). The low yield relative to the conversion value is probably due to oligomerization and/or product decomposition as suggested by TLC and ${ }^{1} \mathrm{H}$ NMR analysis of the crude mixture. A phosphite ligand $\mathrm{P}(\mathrm{OPh})_{3}$, which is comparable to triethynylphosphine L1 in electron-donor ability [58], was slightly more effective than $\mathrm{PPh}_{3}$, but was far less effective than L1 (Table 1, entry 12). Bulky and strongly electron-donating ligands such as X-Phos and IPr were as effective as the electron-deficient ligand $\mathrm{P}(\mathrm{OPh})_{3}$ (Table 1, entries 13 and 14). Accordingly, it is concluded that the acceleration effect by $\mathbf{L} \mathbf{1}$ is not due to an electronic effect rather a steric effect.

The time-conversion profiles shown in Figure 3 clearly indicate that the high catalytic efficiency with $\mathbf{L} 1$ is due to the improvement of the reaction kinetics and not the thermal stability of the catalyst. Although it was reported that $\mathrm{Au}\left(\mathrm{NTf}_{2}\right)$ (IPr) was somewhat unstable in the gold-catalyzed intermolecular hydroamination of alkyne under heating conditions [59], the deactivation of the gold catalyst with IPr and $\mathrm{X}$-Phos was not significant under the present reaction conditions: The reactions with X-Phos and IPr ligands reached 100\% and $84 \%$ conversions after $58 \mathrm{~h}$, respectively (see Supporting Information File 1 for reaction profiles with longer reaction times).

\section{Effect of $\mathrm{N}$-substituents}

While alkynic $o$-nitrotoluenesulfonamide $\mathbf{4 b}$ did not react at all with $0.5 \mathrm{~mol} \%$ of $\left[\mathrm{Au}\left(\mathrm{NTf}_{2}\right)(\mathbf{L 1})\right]$ at room temperature (Table 2, entry 1), this substrate underwent 7-exo-dig cyclization upon increasing catalyst loading to $2.5 \mathrm{~mol} \%$ and heating at $80{ }^{\circ} \mathrm{C}$, giving $N$-nosylazepine derivative $\mathbf{5 b}$ in $76 \%$ isolated 

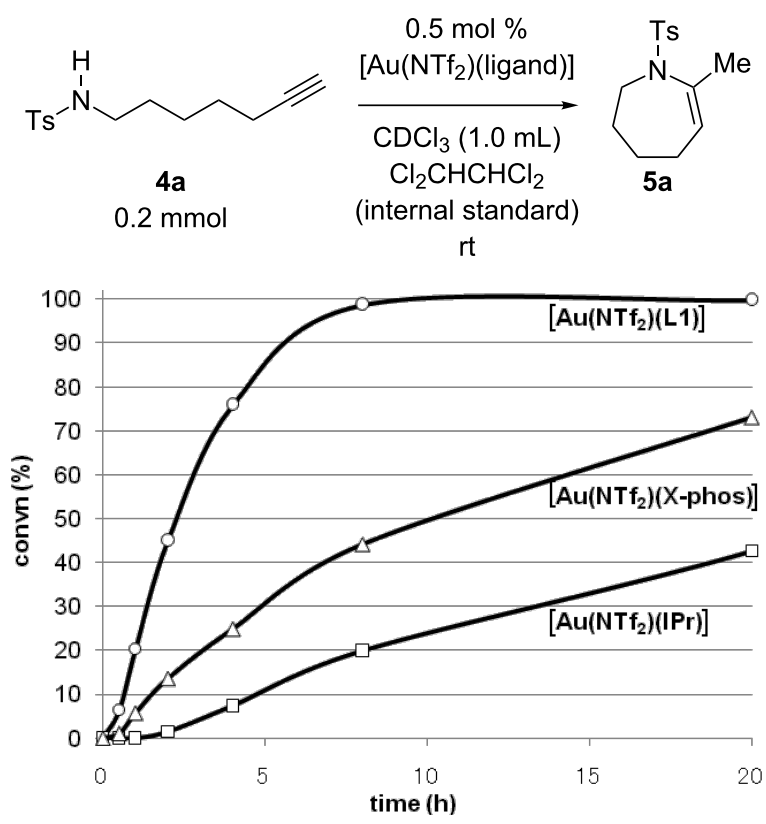

Figure 3: Time-conversion profiles for the gold-catalyzed cyclization of $4 \mathrm{a}$ with $\mathrm{L1}$, X-Phos and IPr ligands. yield (Table 2, entry 2). $N$-Benzyloxycarbonyl (Cbz) and $\mathrm{N}$-acetylazepine derivatives $5 \mathbf{c}$ and $\mathbf{5 d}$ were obtained in low yields through the cyclization of substrates $\mathbf{4 c}$ and $\mathbf{4 d}$ (Table 2, entries 3 and 4). On the other hand, the reactions of the substrates bearing $N$-tert-butoxycarbonyl (Boc) or $N$ - $p$ methoxybenzyl (PMB) groups $(\mathbf{4 e}, \mathbf{f})$ did not give the desired products at all (Table 2, entries 5 and 6). It seems that the reactivity of the substrates is affected by the balance between nucleophilicity of the nitrogen atom and acidity of the $\mathrm{N}-\mathrm{H}$ bond as well as a steric factor.

\section{Effect of substituents in acyclic linkers}

Next, we explored the substrate scope by introducing one or two substituents in the acyclic linker chain of the alkynic $N$-tosylsulfonamide 4a (Table 3). The introduction of the substituents at the $\alpha$ or $\beta$ positions relative to the alkyne moiety caused a significant decrease in the reactivity, but the cyclization of the substituted alkynic sulfonamide $\mathbf{4 g}-\mathbf{l}$ proceeded smoothly, with $2.5-5.0 \mathrm{~mol} \%$ catalyst loading at $80^{\circ} \mathrm{C}$, into full substrate conversion. Specifically, the substrate bearing an $\alpha$-Me group (4g) derived from L-alanine was quantitatively converted into 2,7-dimethyltetrahydroazepine $\mathbf{5 g}$ with $2.5 \mathrm{~mol} \%$ of $\left[\mathrm{Au}\left(\mathrm{NTf}_{2}\right)(\mathbf{L 1})\right](99 \%$ isolated yield, Table 3, entry 1). Although the substitution with bulkier iPr or Bn

Table 2: Effect of $\mathrm{N}$-substitutents.

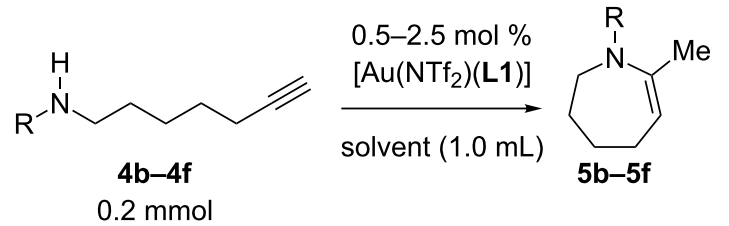

$0.2 \mathrm{mmol}$

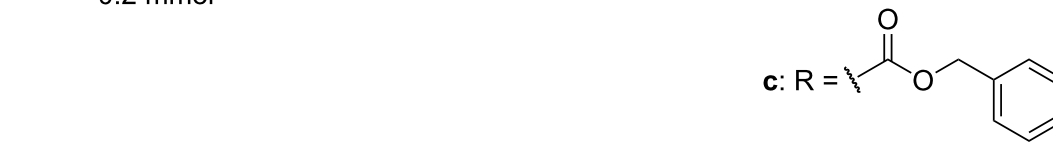

\begin{tabular}{|c|c|c|c|c|c|c|c|}
\hline entry & $\mathrm{R}$ & Au cat. (mol \%) & solvent & temp. $\left({ }^{\circ} \mathrm{C}\right)$ & time (h) & convn. $(\%)^{a}$ & yield of $\mathbf{5}(\%)^{\mathrm{a}}$ \\
\hline 1 & Ns (4b) & 0.5 & $\mathrm{CH}_{2} \mathrm{Cl}_{2}$ & 25 & 18 & 0 & n. d. \\
\hline 2 & Ns (4b) & 2.5 & DCE & 80 & 18 & 100 & $76^{b}$ \\
\hline 3 & $\mathrm{Cbz}(\mathbf{4 c})$ & 2.5 & DCE & 80 & 24 & 97 & 33 \\
\hline 4 & $A c(4 d)$ & 2.5 & DCE & 80 & 24 & 63 & 18 \\
\hline 5 & $\operatorname{Boc}(4 e)$ & 2.5 & DCE & 80 & 24 & 17 & n. d. \\
\hline 6 & PMB (4f) & 2.5 & DCE & 80 & 24 & 0 & n. d. \\
\hline
\end{tabular}

a Determined by ${ }^{1} \mathrm{H}$ NMR. ${ }^{\mathrm{b}}$ Isolated yield. 
groups at the $\alpha$-position in $\mathbf{4 h}$ and $\mathbf{4 i}$ resulted in even lower reactivities, the corresponding cyclization products $\mathbf{5 h}$ and $\mathbf{5 i}$ were obtained in high or good yields (Table 3, entries 2 and 3). The substrates $(\mathbf{4} \mathbf{j}-\mathbf{l})$ with geminal disubstitution at the $\beta$-carbon also participated in the 7-exo-dig cyclization in good yields (Table 3, entries 4-6). Among the cyclization products (5a-1) described above, only the $\beta, \beta$-diphenyl-substituted sulfonamide $5 \mathbf{k}$ was contaminated with a small amount of exomethylene product 6k (Table 3 , entry 5).

It should be noted that the geminal disubstitution in $\mathbf{4} \mathbf{j}-\mathbf{l}$ caused a drastic decrease in the ease of the cyclization, which necessitated much more harsh reaction conditions $\left(5 \mathrm{~mol} \% \mathrm{Au}, 80^{\circ} \mathrm{C}\right.$, 4-12 h, Table 3, entries 4-6) than those for the reaction of the parent substrate $4 \mathbf{a}\left(0.5 \mathrm{~mol} \% \mathrm{Au}, 25^{\circ} \mathrm{C}, 18 \mathrm{~h}\right.$, Table 1 , entry 1). This means that the Thorpe-Ingold effect did not operate in the present case and that the substituents caused steric repulsion hindering the cyclization.

\section{Construction of bicyclic frameworks}

Next, we applied the gold(I)-triethynylphosphine $\mathbf{L} 1$ complex to the construction of bicyclic frameworks such as benzazepine (Table 4). The cyclization of $o$-alkynyl benzylsulfonamide $4 \mathbf{m}$ proceeded with both $\left[\mathrm{Au}\left(\mathrm{NTf}_{2}\right)(\mathbf{L 1})\right]$ and $\left[\mathrm{Au}\left(\mathrm{NTf}_{2}\right)(\mathrm{IPr})\right]$ to give a benzazepine derivative $\mathbf{5 m}$ (Table 4 , entries 1 and 2).
Although the starting material was fully consumed after $3 \mathrm{~h}$ or $6 \mathrm{~h}$, using the respective catalysts, $\mathbf{L 1}$ was superior to IPr with respect to both reaction time and product yield. The reaction of $N$-tosylbenzamide $4 \mathbf{n}$ with $\mathbf{L} \mathbf{1}$ afforded the benzene-fused $\varepsilon$-caprolactam 6n within an exomethylene structure in $97 \%$ yield in an isomerically pure form (vide infra for discussion) (Table 4, entry 3). Sulfonamide 4o, with a cyclohexane-fused linker, also participated in the cyclization to form azabicylo[5.4.0]decene 50 in $76 \%$ yield along with a small amount of exomethylene isomer 6o (5o/6o 98:2, Table 4, entry 4).

\section{Effect of ring sizes}

We also evaluated the triethynylphosphine L1, X-Phos, and IPr for an acceleration effect in the six-membered, ring forming, gold-catalyzed hydroamination of $N$-(5-hexyn-1-yl)- $p$-toluenesulfonamide 7. As expected from entropy considerations, the six-membered ring formations of 7 with these ligands were generally much faster than the seven-membered ring formations of 4: The reaction with $0.5 \mathrm{~mol} \%$ catalyst loading at room temperature completed within $1 \mathrm{~h}$ irrespective of the ligand used. When the catalyst loading was reduced to $0.1 \mathrm{~mol} \%$, however, the superiority of $\mathbf{L 1}$ to X-Phos and IPr became significant, as shown in Table 5. The reaction with $\mathbf{L} \mathbf{1}$ at room temperature afforded the six-membered ring product $\mathbf{8}$ in $91 \%$

Table 3: Cyclization of alkynic sulfonamides with an acyclic linker. ${ }^{a}$

\begin{tabular}{|c|c|c|c|c|c|c|}
\hline entry & substrate & Au cat. (mol \%) & time $(\mathrm{h})$ & convn. $(\%)^{b}$ & product & yield $(\%)^{\mathrm{C}}$ \\
\hline & 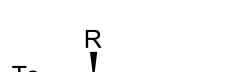 & & & & & \\
\hline 1 & $\mathrm{R}=\mathrm{Me}(\mathbf{4 g})$ & 2.5 & 8 & 100 & $\mathrm{R}=\mathrm{Me}(\mathbf{5 g})$ & 99 \\
\hline 2 & $\mathrm{R}=\mathrm{i} \operatorname{Pr}(\mathbf{4 h})$ & 5.0 & 12 & 100 & $\mathrm{R}=\mathrm{iPr}(5 \mathrm{~h})$ & 88 \\
\hline 3 & $\mathrm{R}=\mathrm{Bn}(\mathbf{4 i})$ & 5.0 & 12 & 100 & $\mathrm{R}=\mathrm{Bn}(\mathbf{5 i})$ & 71 \\
\hline 4 & $\mathrm{R}=\mathrm{Me}(\mathbf{4} \mathbf{j})$ & 5.0 & 4 & 100 & $R=\operatorname{Me}(5 j)$ & 77 \\
\hline 5 & $\mathrm{R}=\mathrm{Ph}(\mathbf{4 k})$ & 5.0 & 4 & 100 & $\mathrm{R}=\mathrm{Ph}(\mathbf{5 k})$ & $69^{d}$ \\
\hline 6 & $\mathrm{R}=-\left(\mathrm{CH}_{2}\right)_{5}-(4 \mathrm{I})$ & 5.0 & 12 & 100 & $\mathrm{R}=-\left(\mathrm{CH}_{2}\right)_{5}-(5 \mathrm{I})$ & 66 \\
\hline
\end{tabular}

aReaction conditions: $4,0.1 \mathrm{mmol}$; $\left[\mathrm{Au}\left(\mathrm{NTf}_{2}\right)(\mathrm{L} 1)\right], 2.5$ or $5 \mathrm{~mol} \%$; DCE, $1.0 \mathrm{~mL} ; 80^{\circ} \mathrm{C}$. betermined by ${ }^{1} \mathrm{H}$ NMR.

'Isolated yield.

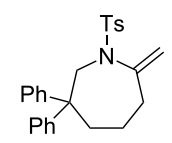

${ }^{d}$ Mixture of $\mathbf{5 k}$ and $\mathbf{6 k}$ in $92: 8$ ratio.

$6 k$ 
Table 4: Cyclization of alkynic sulfonamide with a ring-fused linker. ${ }^{\text {a }}$

entry Au cat. (mol \%) time (h) convn. (\%)

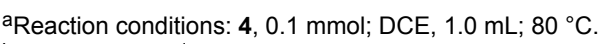

${ }^{b}$ Determined by ${ }^{1} \mathrm{H}$ NMR.

'Isolated yield.

Mixture of 50 and 60 in $98: 2$ ratio.

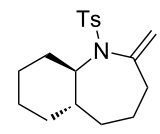

60

\begin{tabular}{|c|c|c|c|c|}
\hline & \multicolumn{3}{|c|}{$\begin{array}{c}0.1 \mathrm{~mol} \% \\
\underset{\left[\mathrm{Au}\left(\mathrm{NTf}_{2}\right)(\text { ligand })\right]}{\longrightarrow} \\
\underset{\mathrm{CH}_{2} \mathrm{Cl}_{2}(1.0 \mathrm{~mL})}{25{ }^{\circ} \mathrm{C}} \\
\text { 6-exo-dig }\end{array}$} & 8 \\
\hline entry & Ligand & $\begin{array}{r}\text { time } \\
(\mathrm{h})\end{array}$ & $\begin{array}{r}\text { convn. } \\
(\%)^{a}\end{array}$ & $\begin{array}{r}\text { yield of } 8 \\
(\%)^{a, b}\end{array}$ \\
\hline 1 & L1 & 2 & 100 & $100(91)$ \\
\hline 2 & X-Phos & 12 & 76 & $76(70)$ \\
\hline 3 & IPr & 12 & 68 & $67(58)$ \\
\hline
\end{tabular}

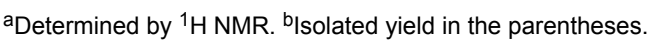

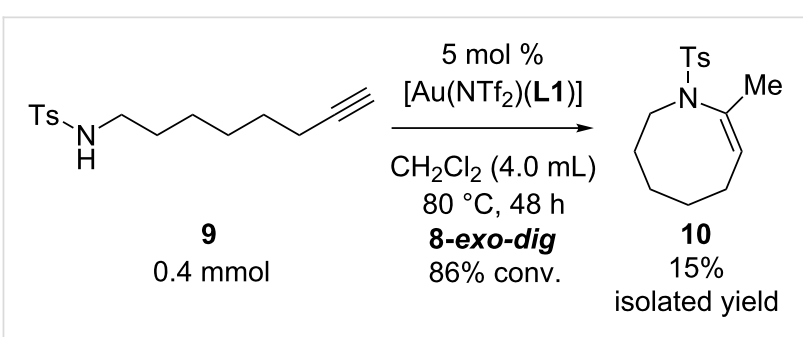

Scheme 1: 8-exo-dig cyclization of sulfonamide 9. isolated yield after $2 \mathrm{~h}$ (Table 1, entry 1). On the other hand, the reaction with $\mathrm{X}$-Phos did not reach full conversion $(76 \%$ convn.) even after $12 \mathrm{~h}$ and gave 8 in only $70 \%$ yield (Table 5 , entry 2). The use of IPr ligand resulted in even lower conversion (68\%) and isolated yield (58\%) (Table 5, entry 3).

The triethynylphosphine ligand $\mathbf{L} \mathbf{1}$ was also evaluated for the eight-membered ring formation of sulfonamide $\mathbf{9}$, which is much more challenging than the seven-membered ring formation of 4 . The reaction required $5 \mathrm{~mol} \%$ catalyst loading under heating conditions $\left(80^{\circ} \mathrm{C}\right)$ in 1,2-dichloroethane for a reasonable conversion rate to afforded an eight-membered ring azocine derivative $\mathbf{1 0}$ in $15 \%$ isolated yield (Scheme 1). It should be noted that the reaction produced significant amounts of unidentified oligomeric side products.

\section{Alkene isomerization}

We carried out alkene isomerization experiments to clarify how tetrahydroazepines 5 formed via the 7-exo-dig cyclization of 4 . One possible reaction pathway is the alkene isomerization of an exomethylene product $\mathbf{6}$. To test this possibility, we synthesized 6a through another route (see Supporting Information File 1) and subjected it to the standard reaction conditions of the gold-triethynylphosphine-catalyzed cyclization of alkynic sulfonamide with or without $N$-tosyl aniline 7 as an external 


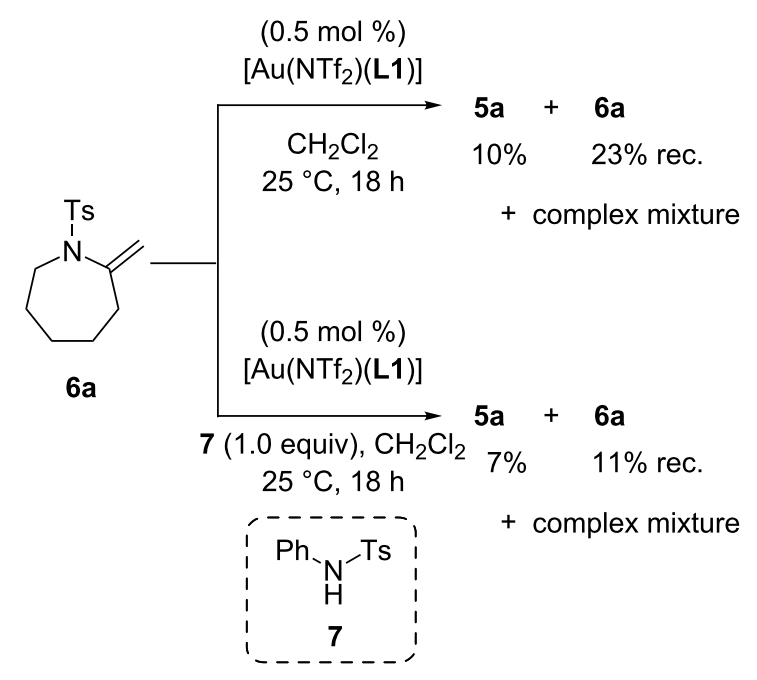

Scheme 2: Isomerization experiments of $6 \mathbf{a}$

proton source (Scheme 2). Although 6a was indeed isomerized into 5a to some extent in both cases, the main reaction was decomposition to give complex mixtures. The exomethylene substrate 6a appeared to be unstable at room temperature even in the absence of the gold-catalyst.

According to these results, the formation of exomethylene compound $\mathbf{6}$ and subsequent alkene isomerisation should not be a major pathway to $\mathbf{5}$. Instead, a possible reaction pathway from 4a to 5a is illustrated in Figure 4. First, the cationic gold center coordinates with 4a to form the gold-alkyne complex A. Intramolecular nucleophilic attack of the nitrogen atom affords the 7-exo-dig cyclization product $\mathbf{B}$ with an exocyclic $\mathrm{C}-\mathrm{C}$ double bond. The protonated $N$-sulfonylenamide B tautomerizes to iminium ion $\mathbf{C}$ through 1,3-proton shift, or through an alternative pathway via a gold(I)-carben intermediate (D). Then, re-tautomerization affords the protonated $N$-sulfonylenamide $\mathbf{E}$ with an endocyclic $\mathrm{C}-\mathrm{C}$ double bond. Finally, protodemetalation of $\mathbf{E}$ give the $N$-sulfonylenamide $\mathbf{5 a}$, which is thermodynamically more stable than $\mathbf{6 a}$.

It should be noted that the reaction of the $N$-tosylbenzamide $4 \mathbf{n}$ afforded exceptionally the exomethylene isomer $6 \mathbf{n}$. One conceivable reason is that the alkene isomerisation was prevented due to a ring strain in the seven-membered ring of $\mathbf{5 n}$, of which six out of seven atoms are $\mathrm{sp}^{2}$-hybridized.

\section{Conclusion}

We demonstrated that the 7-exo-dig intramolecular hydroamination of $\omega$-alkynic $N$-alkyl- $N$-sulfonamides is efficiently catalyzed by a gold(I) complex coordinated with the semihollow-shaped triethynylphopshine ligand $\mathbf{L 1}$, and that the cyclization protocol provides a new efficient route to $\mathrm{N}$-containing seven-membered ring compounds. The protocol is applicable to the reaction of alkynic sulfonamides with an acyclic or ring-fused linker chain with various substitution patterns. Evaluation of the ligand effect in the gold catalysis

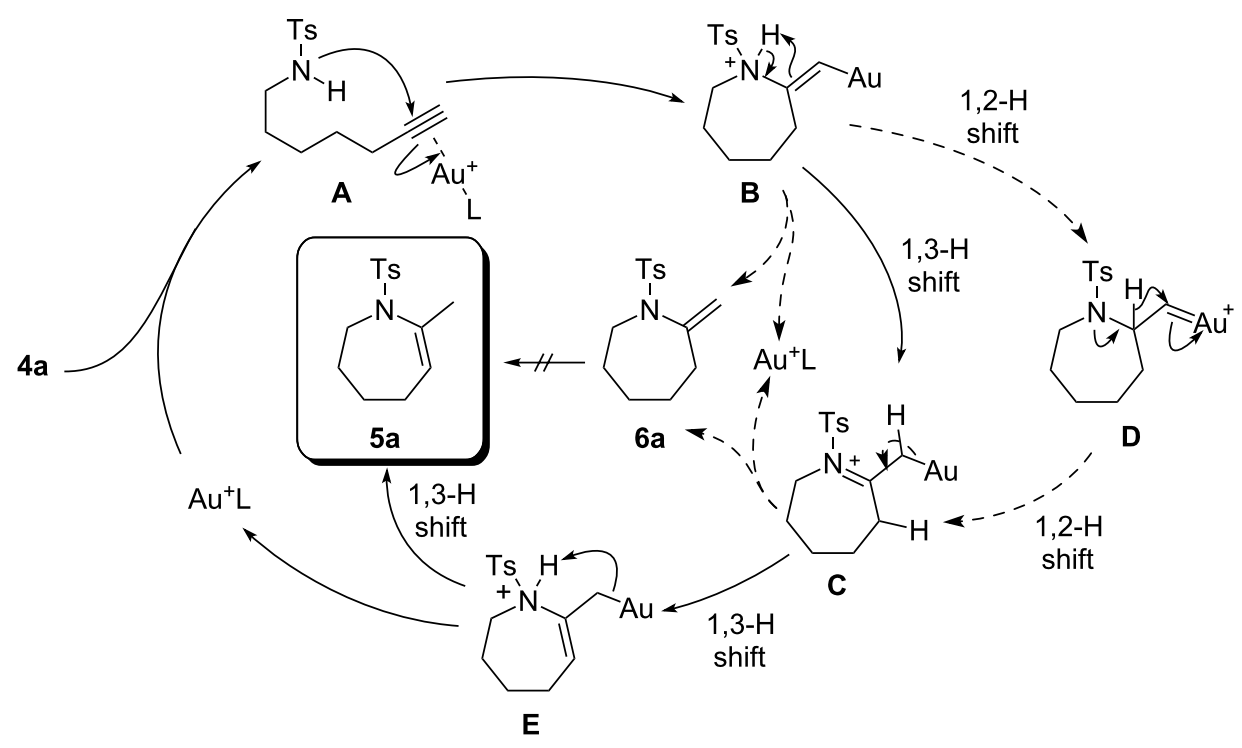

Figure 4: Possible pathway for the gold-catalyzed conversion of $\mathbf{4 a}$ into $\mathbf{5 a}$. 
with different ligands and substrates strongly suggested that the rate enhancement by the triethynylphosphine would be due to a steric factor which enforces a nucleophilic center close to a gold-activated alkyne moiety.

\section{Experimental}

\section{Preparation of $\left[\mathrm{Au}\left(\mathrm{NTf}_{2}\right)(\mathrm{L} 1)\right]$}

$[\mathrm{AuCl}(\mathbf{L 1})]$ (1 equiv) was placed in an open vial and was dissolved in $\mathrm{CH}_{2} \mathrm{Cl}_{2}$ (ca. $0.1 \mathrm{M}$ ). $\operatorname{AgNTf}_{2}(>1.5$ equiv) was added, and the mixture was stirred at $25{ }^{\circ} \mathrm{C}$ for $10 \mathrm{~min}$. The resulting white suspension was filtered through celite into a screw vial. The resulting colorless solution was first concentrated with a stream of Ar gas and then dried in vacuo to give $\left[\mathrm{Au}\left(\mathrm{NTf}_{2}\right)(\mathbf{L 1})\right]$ as a white solid. (See also [55].)

\section{General procedure for gold-catalyzed intramolecular hydroamination of alkynic sulfonamide $\mathbf{4 a}$}

$\left[\mathrm{Au}\left(\mathrm{NTf}_{2}\right)(\mathbf{L 1})\right](2.6 \mathrm{mg}, 1.0 \mu \mathrm{mol}, 0.5 \mathrm{~mol} \%)$ and a magnetic stirring bar were placed in an open vial. Separately, the alkynyl sulfonamide 4a ( $55 \mathrm{mg}, 0.20 \mathrm{mmol}$ ) was weighted into a micro tube. The tubes were placed in a glove box. The gold complex and $4 \mathbf{a}$ were dissolved in degassed dry $\mathrm{CH}_{2} \mathrm{Cl}_{2}(0.25 \mathrm{~mL})$, in their respective tubes. The solution of $\mathbf{4 a}$ was transferred to the solution of the catalyst with a syringe. The remaining solutions in the micro tube and the syringe were washed with $\mathrm{CH}_{2} \mathrm{Cl}_{2}$ $(2 \times 0.25 \mathrm{~mL})$ and, the washings were added to the reaction mixture. The tube was sealed with a cap equipped with a Teflon-coated silicon rubber septum. The tube was taken from the glove box, and was placed in a water bath $\left(25^{\circ} \mathrm{C}\right)$. After the reaction was complete (as monitored by TLC), the reaction mixture was passed through a pad of silica gel and was concentrated to dryness. Purification by flash chromatography on silica gel gave the cyclization product $\mathbf{5 a}(45 \mathrm{mg}, 82 \%)$ as a white solid; mp 65.8-66.1 ${ }^{\circ} \mathrm{C} ;{ }^{1} \mathrm{H}$ NMR $\left(300 \mathrm{MHz}, \mathrm{CDCl}_{3}\right) \delta$ $1.32-1.53(\mathrm{~m}, 6 \mathrm{H}), 1.94(\mathrm{t}, J=2.7 \mathrm{~Hz}, 1 \mathrm{H}), 2.14(\mathrm{td}, J=6.9$, $2.7 \mathrm{~Hz}, 2 \mathrm{H}), 2.44$ (s, 3H), 2.95 (q, $J=6.9 \mathrm{~Hz}, 2 \mathrm{H}), 4.34$ (br s, $1 \mathrm{H}), 7.31(\mathrm{~d}, J=8.1 \mathrm{~Hz}, 2 \mathrm{H}), 7.75(\mathrm{~d}, J=8.1 \mathrm{~Hz}, 2 \mathrm{H}) ;{ }^{13} \mathrm{C}$ NMR (75 MHz, $\left.\mathrm{CDCl}_{3}\right) \delta 17.94,21.29,25.34,27.59,28.75$, 42.80, 68.35, 84.05, 127.06, 129.90, 136.85, 143.34; Anal. calcd for $\mathrm{C}_{14} \mathrm{H}_{19} \mathrm{NO}_{2} \mathrm{~S}$ : C, 63.36; H, 7.22; N, 5.28; found: $\mathrm{C}$, 63.29; H, 7.16; N, 5.21.

\section{Supporting Information}

\section{Supporting Information File 1}

Experimental procedures and NMR spectra for $\mathbf{4 a - 0}$ and

5a, b, g-m, o, 6a, n, 7, 8, 9, 10.

[http://www.beilstein-journals.org/bjoc/content/

supplementary/1860-5397-7-106-S1.pdf]

\section{Acknowledgements}

This work was supported by Grants-in-Aid for Scientific Research on Priority Area "Chemistry of Concerto Catalysis" from MEXT. H.I. thanks JSPS for a fellowship.

\section{References}

1. Uyeo, S.; Irie, H.; Harada, H. Chem. Pharm. Bull. 1967, 15, 768-770.

2. Harada, H.; Irie, H.; Masaki, N.; Osaki, K.; Uyeo, S. Chem. Commun. (London) 1967, 460-462. doi:10.1039/c19670000460

3. Götz, M.; Bögri, T.; Gray, A. H.; Strunz, G. M. Tetrahedron 1968, 24, 2631-2643. doi:10.1016/S0040-4020(01)82538-2

4. Lin, W.-H.; Ye, Y.; Xu, R.-S. J. Nat. Prod. 1992, 55, 571-576. doi:10.1021/np50083a003

5. Pilli, R. A.; Ferreira de Oliveira, M. C. Nat. Prod. Rep. 2000, 17, 117-127. doi:10.1039/a902437i

6. Wipf, P.; Rector, S. R.; Takahashi, H. J. Am. Chem. Soc. 2002, 124, 14848-14849. doi:10.1021/ja028603t

7. Alibés, R.; Figueredo, M. Eur. J. Org. Chem. 2009, 2009, 2421-2435. doi:10.1002/ejoc.200900037

8. Paudler, W. W.; Kerley, G. I.; McKay, J. J. Org. Chem. 1963, 28, 2194-2197. doi:10.1021/jo01044a010

9. Weinreb, S. M.; Semmelhack, M. F. Acc. Chem. Res. 1975, 8, 158-164. doi:10.1021/ar50089a003

10. Huang, L.; Xue, Z. Cephalotaxus alkaloids. In The Alkaloids: Chemistry and Pharmacology; Brossi, A., Ed.; Academic Press: New York, 1984; Vol. 23, pp 157-226. doi:10.1016/S0099-9598(08)60071-1

11. Jalil Miah, M. A.; Hudlicky, T.; Reed, J. W. Cephalotaxus Alkaloids. In The Alkaloids: Chemistry and Biology; Cordell, G. A., Ed.; Academic Press: San Diego, 1998; Vol. 51, pp 199-269. doi:10.1016/S0099-9598(08)60006-1

12. Isono, N.; Mori, M. J. Org. Chem. 1995, 60, 115-119. doi:10.1021/jo00106a023

13. Kumar, S.; Dare, L.; Vasko-Moser, J. A.; James, I. E.; Blake, S. M.; Rickard, D. J.; Hwang, S.-M.; Tomaszek, T.; Yamashita, D. S.; Marquis, R. W.; Oh, H.; Jeong, J. U.; Veber, D. F.; Gowen, M.; Lark, M. W.; Stroup, G. Bone 2007, 40, 122-131. doi:10.1016/j.bone.2006.07.015

14. Yamashita, D. S.; Marquis, R. W.; Xie, R.; Nidamarthy, S. D.; Oh, H.-J.; Jeong, J. U.; Erhard, K. F.; Ward, K. W.; Roethke, T. J.; Smith, B. R.; Cheng, H.-Y.; Geng, X.; Lin, F.; Offen, P. H.; Wang, B.; Nevins, N.; Head, M. S.; Haltiwanger, R. C.; Narducci Sarjeant, A. A.; Liable-Sands, L. M.; Zhao, B.; Smith, W. W.; Janson, C. A.; Gao, E.; Tomaszek, T.; McQueney, M.; James, I. E.; Gress, C. J.; Zembryki, D. L.; Lark, M. W.; Veber, D. F. J. Med. Chem. 2006, 49, 1597-1612. doi:10.1021/jm050915u

15. Wang, H.; Matsuhashi, H.; Doan, B. D.; Goodman, S. N.; Ouyang, X.; Clark, W. M., Jr. Tetrahedron 2009, 65, 6291-6303. doi:10.1016/j.tet.2009.06.022

16. Goodman, S. N.; Dai, Q.; Wang, J.; Clark, W. M., Jr. Org. Process Res. Dev. 2011, 15, 123-130. doi:10.1021/op100266s

17. Müller, T. E.; Beller, M. Chem. Rev. 1998, 98, 675-704. doi:10.1021/cr960433d

18. Müller, T. E.; Hultzsch, K. C.; Yus, M.; Foubelo, F.; Tada, M. Chem. Rev. 2008, 108, 3795-3892. doi:10.1021/cr0306788

19. Hashmi, A. S. K. Chem. Rev. 2007, 107, 3180-3211. doi:10.1021/cr000436x

20. Li, Z.; Brouwer, C.; He, C. Chem. Rev. 2008, 108, 3239-3265. doi:10.1021/cr068434I

21. Arcadi, A. Chem. Rev. 2008, 108, 3266-3325. doi:10.1021/cr068435d 
22. Gorin, D. J.; Sherry, B. D.; Toste, F. D. Chem. Rev. 2008, 108, 3351-3378. doi:10.1021/cr068430g

23. Patil, N. T.; Yamamoto, Y. Chem. Rev. 2008, 108, 3395-3442. doi:10.1021/cr050041j

24. Hashmi, A. S. K.; Rudolph, M. Chem. Soc. Rev. 2008, 37, 1766-1775. doi:10.1039/b615629k

25. Marion, N.; Nolan, S. P. Chem. Soc. Rev. 2008, 37, 1776-1782. doi:10.1039/b711132k

26. Shapiro, N. D.; Toste, F. D. Synlett 2010, 675-691. doi:10.1055/s-0029-1219369

27. Corma, A.; Leyva-Pérez, A.; Sabater, M. J. Chem. Rev. 2011, 111, 1657-1712. doi:10.1021/cr100414u

28. Krause, N.; Winter, C. Chem. Rev. 2011, 111, 1994-2009. doi:10.1021/cr1004088

29. Shu, X.-Z.; Liu, X.-Y.; Xiao, H.-Q.; Ji, K.-G.; Guo, L.-N.; Liang, Y.-M. Adv. Synth. Catal. 2008, 350, 243-248. doi:10.1002/adsc.200700452

30. Enomoto, T.; Obika, S.; Yasui, Y.; Takemoto, Y. Synlett 2008, 1647-1650. doi:10.1055/s-2008-1077879

31. Ye, D.; Wang, J.; Zhang, X.; Zhou, Y.; Ding, X.; Feng, E.; Sun, H.; Liu, G.; Jiang, H.; Liu, H. Green Chem. 2009, 11, 1201-1208. doi:10.1039/b904044g

32. Peng, H. M.; Zhao, J.; Li, X. Adv. Synth. Catal. 2009, 351, 1371-1377. doi:10.1002/adsc.200800735

33. Ye, D.; Zhang, X.; Zhou, Y.; Zhang, D.; Zhang, L.; Wang, H.; Jiang, H.; Liu, H. Adv. Synth. Catal. 2009, 351, 2770-2778. doi:10.1002/adsc.200900505

34. Liu, X.-Y.; Che, C.-M. Org. Lett. 2009, 11, 4204-4207. doi:10.1021/ol901443b

35. Yamane, Y.; Liu, X.; Hamasaki, A.; Ishida, T.; Haruta, M.; Yokoyama, T.; Tokunaga, M. Org. Lett. 2009, 11, 5162-5165. doi:10.1021/ol902061j

36. Zhou, Y.; Feng, E.; Liu, G.; Ye, D.; Li, J.; Jiang, H.; Liu, H. J. Org. Chem. 2009, 74, 7344-7348. doi:10.1021/jo901418m

37. Enomoto, T.; Girard, A.-L.; Yasui, Y.; Takemoto, Y. J. Org. Chem. 2009, 74, 9158-9164. doi:10.1021/jo901906b

38. Han, Z.-Y.; Xiao, H.; Chen, X.-H.; Gong, L.-Z. J. Am. Chem. Soc. 2009, 131, 9182-9183. doi:10.1021/ja903547q

39. Wilckens, K.; Uhlemann, M.; Czekelius, C. Chem.-Eur. J. 2009, 15, 13323-13326. doi:10.1002/chem.200901702

40. Hirano, K.; Inaba, Y.; Watanabe, T.; Oishi, S.; Fujii, N.; Ohno, H. Adv. Synth. Catal. 2010, 352, 368-372. doi:10.1002/adsc.200900880

41.Zeng, X.; Kinjo, R.; Donnadieu, B.; Bertrand, G. Angew. Chem., Int. Ed. 2010, 49, 942-945. doi:10.1002/anie.200905341

42. Hashmi, A. S. K.; Ramamurthi, T. D.; Rominger, F. Adv. Synth. Catal. 2010, 352, 971-975. doi:10.1002/adsc.201000011

43. Patil, N. T.; Singh, V.; Konala, A.; Mutyala, A. K. Tetrahedron Lett. 2010, 51, 1493-1496. doi:10.1016/j.tetlet.2010.01.036

44. Gimeno, A.; Medio-Simón, M.; Ramírez de Arellano, C.; Asensio, G.; Cuenca, A. B. Org. Lett. 2010, 12, 1900-1903. doi:10.1021/ol100595s

45. Wang, C.; Han, Z.-Y.; Luo, H.-W.; Gong, L.-Z. Org. Lett. 2010, 12 , 2266-2269. doi:10.1021/ol1006086

46. Zhang, L.; Ye, D.; Zhou, Y.; Liu, G.; Feng, E.; Jiang, H.; Liu, H. J. Org. Chem. 2010, 75, 3671-3677. doi:10.1021/jo100378u

47. Kothandaraman, P.; Rao, W.; Foo, S. J.; Chan, P. W. H. Angew. Chem., Int. Ed. 2010, 49, 4619-4623. doi:10.1002/anie.201000341

48. Demir, A. S.; Emrullahoğlu, M.; Buran, K. Chem. Commun. 2010, 46, 8032-8034. doi:10.1039/c0cc02357d

49. Monge, D.; Jensen, K. L.; Franke, P. T.; Lykke, L.; Jørgensen, K. A. Chem.-Eur. J. 2010, 16, 9478-9484. doi:10.1002/chem.201001123
50. Arcadi, A.; Abbiati, G.; Rossi, E. J. Organomet. Chem. 2011, 696, 87-98. doi:10.1016/j.jorganchem.2010.08.011

51. Kitahara, H.; Sakurai, H. J. Organomet. Chem. 2011, 696, 442-449. doi:10.1016/j.jorganchem.2010.08.038

52. Zulys, A.; Dochnahl, M.; Hollmann, D.; Löhnwitz, K.; Herrmann, J.-S.; Roesky, P. W.; Blechert, S. Angew. Chem., Int. Ed. 2005, 44, 7794-7798. doi:10.1002/anie.200502006

53. Yu, Y.; Stephenson, G. A.; Mitchell, D. Tetrahedron Lett. 2006, 47, 3811-3814. doi:10.1016/j.tetlet.2006.03.198

54. Liu, J.; Shen, M.; Zhang, Y.; Li, G.; Khodabocus, A.; Rodriguez, S.; Qu, B.; Farina, V.; Senanayake, C. H.; Lu, B. Z. Org. Lett. 2006, 8, 3573-3575. doi:10.1021/ol061440j

55. Ochida, A.; Ito, H.; Sawamura, M. J. Am. Chem. Soc. 2006, 128, 16486-16487. doi:10.1021/ja066800c

56. Ito, H.; Makida, Y.; Ochida, A.; Ohmiya, H.; Sawamura, M. Org. Lett. 2008, 10, 5051-5054. doi:10.1021/ol802079r

57. Ito, H.; Ohmiya, H.; Sawamura, M. Org. Lett. 2010, 12, 4380-4383. doi:10.1021/ol101860j

58. Ochida, A.; Sawamura, M. Chem.-Asian J. 2007, 2, 609-618. doi:10.1002/asia.200700006

59. Duan, H.; Sengupta, S.; Petersen, J. L.; Akhmedov, N. G.; Shi, X. J. Am. Chem. Soc. 2009, 131, 12100-12102. doi:10.1021/ja9041093

\section{License and Terms}

This is an Open Access article under the terms of the Creative Commons Attribution License (http://creativecommons.org/licenses/by/2.0), which permits unrestricted use, distribution, and reproduction in any medium, provided the original work is properly cited.

The license is subject to the Beilstein Journal of Organic Chemistry terms and conditions:

(http://www.beilstein-journals.org/bjoc)

The definitive version of this article is the electronic one which can be found at: doi:10.3762/bjoc.7.106 